\title{
FACTORS INFLUENCING THE EFFICIENCY OF MALAYSIAN LOCAL GOVERNMENTS
}

\author{
JULIA MOHD SAID 1 \\ HUSNIYATI MOHD AMIN ${ }^{1}$ \\ SUHAIZA ISMAIL ${ }^{1}$, *
}

Received: 13 September 2019 / Revised: 20 November 2019, 12 January 2020 / Accepted: 23 January 2020 (C) 2020 Faculty of Business and Accountancy, University of Malaya. All rights reserved.

\section{A B S T R ACT}

Research aim: This paper investigates the factors influencing the efficiency of Malaysian local governments. Three measures of efficiency are considered, namely (i) technical efficiency (TE), (ii) pure technical efficiency (PTE) and (iii) scale efficiency (SE).

Design/ Methodology/ Approach: This study uses secondary data from annual financial statements of local governments in Malaysia. Financial statements from 2008 to 2015 from 35 local governments were obtained. Panel regression based on the ordinary least square was used to examine the determinants of efficiency of the Malaysian local governments.

Research findings: The results reveal that the population size and value of assets have positive and significant influence on the PTE, economic independence has positive and significant influence on the TE and SE, while the dependence on tax revenues is found negatively and significantly associated with all the three measures of efficiency (i.e. TE, PTE and SE).

Originality/value: The paper provides empirical evidence on the determinants of efficiency of local governments in Malaysia. More importantly, the investigation on the factors was carried out for three measures of efficiency that are TE, PTE and SE.

Practitioner/ Policy implication: The findings offer useful information to the relevant local governments in improving their efficiency.

Research limitation: The present study has focused only on examining the efficiency of local government and has not been able to assess the effectiveness of these services

Keywords: Determinants for Efficiency, Local Government, Malaysia,

Type of article: Research paper

JEL Classification: H72

\section{Introduction}

Local government, being the government level nearest to the citizen, is responsible for providing goods and services to the people living within its localities or areas (Ibrahim \& Karim, 2004; Fogarty \& Mugera, 2013; Da Cruz \& Marques, 2014). The provision of goods and services by the local government is wide-ranging. Among the common services provided by the local government are waste collection, street lighting, road maintenance, development and maintenance of leisure amenities, recreational facilities and activities related to public health (Ibrahim \& Karim, 2004; Balaguer-Coll et al., 2007; Geys \& Moesen, 2009; Ngah et al., 2011; Fogarty \& Mugera, 2013; Doumpos \& Cohen, 2014).

The rapid changes in the global environment and the growth of citizens' demands for a diverse range of services and facilities create challenges for local governmentss (Phang, 2008; Benito et al., 2010; Ngah et al., 2011). The challenges

\footnotetext{
* Corresponding author. ${ }^{1}$ Kulliyyah of Economics and Management Sciences, International Islamic University Malaysia, 50728 Kuala Lumpur, Malaysia. Email: Said, J.M. (julia@iium.edu.my), Amin, H.M. (husniyati_ma@yahoo.com), Ismail, S. (suhaiza@iium.edu.my)
} 
include the wider scope of services and higher expectation on the quality and efficiency of the facilities and services provided (Ghobadian \& Ashworth, 1994; Phang, 2008). A local government is expected to utilise its financial resources in providing quality goods and services to the public efficiently (Ghobadian \& Ashworth, 1994; Renne, 1937 as cited in Da Cruz \& Marques, 2014; Doumpos \& Cohen, 2014). However, statistics from the Public Complaints Bureau (2016) show that the public's complaints about local governments' service quality have been increasing from year to year.

Moreover, despite the various initiatives taken by the local government authorities, such as the introduction of the MS ISO 9000 quality system (Abdullah et al., 2013) and the revision of the act on Solid Waste and Public Cleansing Management (Yahaya \& Larsen, 2008) to improve the efficiency of their service delivery, the number of complaints about local governments remains high. Therefore, it is crucial to understand the factors that contribute to the efficiency of local governments to facilitate further efforts to improve the quality of their service delivery. Thus, in attempting to address the issue, using contingency theory, the present study aims at investigating the factors affecting efficiency of the local government in Malaysia. The present study performs the standard DEA models in measuring the efficiency level particularly the technical efficiency (TE), which can be split into two pure technical efficiency (PTE) and scale efficiency (SE).

There are several motivations for the current study. Firstly, the endless public complaints about the Malaysian local government have raised questions for the researcher. Secondly, the researcher realised that examining the level of efficiency solely may not be sufficient for understanding the performance of local government in Malaysia. The difference in efficiency levels of different local governments may be influenced by factors particular to each local government (Da Cruz \& Marques, 2014). Hence, the present study attempts to identify factors affecting local government's efficiency levels. Thirdly, the findings of the present study contribute to the existing literature on the efficiency of local government in Malaysia by providing an analysis of influencing factors. This knowledge may motivate local governments to initiate proactive measures for efficiency improvement.

The remainder of this paper is structured as follows. The following section provides a review of related prior studies, theoretical framework as well as the hypotheses development. Then, a section discusses on the methods used in the study and variables used in the panel regression analysis is provided. The findings are presented in subsequent section. The final section provides discussions on the implications, limitations, suggestions for future study and a conclusion.

\section{Theoretical Framework, Literature Review and Hypotheses Development 2.1. Contingency Theory}

Contingency theory posits that organisations are forced to fit and adapt to the contingencies that reflect the situation of the organisation to avoid loss of performance (Donalson, 2001). The organisations' facility in fitting characteristics to contingencies (which includes the environment, organisational size and organisational strategy) determines the success of their performance. The level of performance improves if there is a good fit and declines if otherwise (Nurkholis, 
2012). As such, the theory asserts that there is a relationship between the structures of organisations and the contingencies which give effect to the organisations' performance (Burrel \& Morgan, 1979 as cited in Donaldson, 2001).

Contingencies can be in the form of internal and external contingencies (Grötsch et al., 2013). Among the various contingencies that may affect organisations' performance are organisation size, organisation strategy, technology, culture and leadership (Wadongo \& Abdel-Kader, 2014) and uncertainty of actions by stakeholders such as customers and regulatory groups (Govindarajan, 1984 as cited in Rayburn \& Gayle Rayburn 1991). Efficiency is a measurement of performance. The efficiency of the local government is considered as the result of local government's actions towards the inputs provided. In the process of finding the most appropriate processes, local governments have to face several internal and external variables which have an impact on their strategies and actions that determine their performance. Hence, contingency theory is a suitable framework for identifying factors that influence the local government's efficiency.

\subsection{Literature Review and Hypotheses Development}

Prior studies on efficiency of local government can be classified into two categories. The first category refers to studies that examine the efficiency of local governments in general (Ibrahim \& Karim, 2004; Io Storto, 2013; Balaguer-Coll et al., 2007; Revelli \& Tovmo, 2007; Fogarty \& Mugera, 2013; Da Cruz \& Marques, 2014; Doumpos \& Cohen, 2014), and the second category covers studies that evaluate the efficiency of a specific service provided by the local government (Osman et al., 2014; Ngah et al., 2011; Woodbury \& Dollery, 2004; Aristovnik et al., 2014; Benito et al., 2010; Benito-López et al., 2011; Lopez et al., 2009; GarcíaSánchez, 2006; Drake \& Simper, 2003; Wibowo \& Alfen, 2015). As well as the studies on efficiency level, numerous studies investigated factors affecting efficiencies of local government. Several factors were found to be associated with local government efficiency, including grants (De Borger \& Kerstens, 1996; Loikkanen \& Susiluoto, 2006; Balaguer-Coll et al., 2007; Doumpos \& Cohen, 2014), tax revenues, population size (Loikkanen \& Susiluto, 2006; Da Cruz \& Marques, 2014), population density (Geys \& Moesen, 2009; Benito-López et al., 2011; Da Cruz \& Marques, 2014; Doumpos \& Cohen, 2014), population education levels (Loikkanen \& Susiluto, 2006; Da Cruz \& Marques, 2014), population income levels (Benito-López et al., 2011; De Borger \& Kerstens, 1996) and unemployment rate (Loikkanen \& Susiluto, 2006).

Despite numerous studies on local government efficiency, most of the research on efficiency involves developed countries (Balaguer-Coll et al., 2007; Da Cruz \& Marques, 2014; Fogarty \& Mugera, 2013; Doumpus \& Cohen, 2014). Developed countries are known for their high per capita income and stable population growth rate. These characteristics are very different from the developing countries, such as Malaysia, which have lower per capita income levels and a high population growth rate. Consequently, research conducted in developed countries may come to conclusions different from those of research conducted in developing countries because of the difference in economic background. Also contributing to differences in research findings are aspects of geography, politics and culture. As 
a consequence, the results of most efficiency studies in developed countries may not apply to developing countries. Therefore, research on efficiency in developing countries may provide more relevant findings for local governments in countries such as Malaysia.

Additionally, the mixed results on the factors influencing local government in prior studies suggest that these factors have different levels of influence on the efficiency of individual local governments. A particular factor may positively affect the efficiency of some local governments but negatively affect the efficiency of others or have no effect on efficiency at all. Accordingly, the study also examines several of these factors to identify the factors that may influence the efficiency of Malaysian local government. As this study examines the factors influencing the efficiency of local governments in Malaysia, the subsequent sub-sections offer the hypotheses development for each variable tested in the present study: population size, population density, economic independence, dependence on tax revenue and the value of assets.

\subsubsection{Population Size and Efficiency}

Population size can be considered one of the contingencies that affect an organisation's performance (Hauner, 2008; Doumpos \& Cohen, 2014; Wibowo \& Alfen, 2015). The population size is closely related to the size of the local government where the larger local governments are associated with higher population size. Larger local governments have a stronger organisational structure and advanced systems than smaller local governments. These advantages allow larger local governments to become more efficient in their operations and provide higher-quality public services.

Moreover, larger local governments receive more funding in terms of grant amounts which allow them to utilise the funding to provide better-quality facilities and services to the public. Hence, larger local governments tend to be more efficient (Hauner, 2008; Doumpos \& Cohen, 2014; Wibowo \& Alfen, 2015). In examining six different Spanish local governments, Benito et al. (2010) revealed that among the positive relationships found between population size and the efficiency of culture, sports, green area and water supply services of local government, only water supply correlates significantly with efficiency due mainly to economies of scale. Operating at economies of scale allows savings in costs as the level of production increases. Therefore, local governments are deemed efficient in managing their resources, i.e. machinery, factory space, labour and other inputs (Wibowo \& Alfen, 2015).

In contrast, some studies reveal that local governments face difficulties in managing a large population size, and this negatively affects their service provision efficiency (Ibrahim \& Karim, 2004; Loikkanen \& Susiluto, 2006). A smaller population size associated with smaller local government is easier to manage and leads to higher efficiency of the local government. Despite the arguments on the negative impact of the population size, this study predicts a positive association between the population size and the local government's efficiency. Higher population promotes higher productivity in the local government, indicated by the higher technical efficiency (TE) scores. Pure technical efficiency (PTE) scores are also higher. Due to stronger organisational 
structure and advanced systems, a large local government is able to utilise its resources more systematically in producing the services. A large population also leads to higher scale efficiency (SE) as the large local government has more ability to optimise their scale of operation. Therefore, three separate hypotheses are developed to test the relationship.

H1a: There is a positive relationship between population size and technical efficiency.

H1b: There is a positive relationship between population size and pure technical efficiency.

H1c: There is a positive relationship between population size and scale efficiency.

\subsubsection{Population Density and Efficiency}

Density of the population is a potential factor influencing a local government's efficiency (Benito et al., 2010). High population density refers to a high number of citizens per square kilometre. A local government serving a highly dense area would be perceived as being efficient because a higher number of people utilise the services provided. The cost per unit of operation becomes smaller because the fixed cost is spread out over more units of output.

High population density encourages better performance because the local government may focus their resources in a dense area compared to the distribution of resources to several different areas. Local government is able to provide the same level of services to more citizens. This enables a reduced cost for service delivery due to better economies of scale (Hauner, 2008; De Borger \& Kerstens, 1996). Benito et al. (2010) reveal that the only significant relationship is found in green areas, since the high-density the population makes maintenance services more difficult, whereas, for the other services, population density is positive but weakly associated with efficiency for all services.

In contrast, some studies reveal a negative relationship between the population density and local government efficiency levels (Geys \& Moesen, 2009; BenitoLópez et al., 2011; Da Cruz \& Marques, 2014; Doumpos \& Cohen, 2014). Higher density causes the costs of public service provision to increase as the high volume of waste generated makes refuse collection and street cleaning more challenging and decreases the local government's efficiency level (Geys \& Moesen, 2009; Benito-López et al., 2011).

Nevertheless, for this study, the researcher predicts a positive association between population density and local government efficiency. There would be high PTE because the population's concentration allows the local government to focus its services in a particular area, and thus efficiently organises their inputs (resources) for production. The SE scores would be higher in a high-density area because the resources used by the local government are able to produce services that are used by more people. As the PTE and SE scores are high, the TE will also be recorded high, indicating that the local government can maximise its output from the minimum quantity of inputs. Therefore, for this study, three separate hypotheses are created to test the relationship. 
H2a: There is a positive relationship between population density and technical efficiency.

$H 2 b$ : There is a positive relationship between population density and pure technical efficiency.

$\mathrm{H} 2 \mathrm{c}$ : There is a positive relationship between population density and scale efficiency.

\subsubsection{Economic Independence and Efficiency}

Economic independence for local governments means less dependence on central grants or subsidies (Loikkanen \& Susiluoto, 2005; Fogarty \& Mugera, 2013; Doumpos \& Cohen, 2014). Grants or subsidies can make local governments complacent and less motivated to improve their services because they know that grants will be provided continuously. Moreover, higher economic independence means that the local government has to put more effort into securing income from other sources, such as taxes and fees. Having to invest effort in efficiently managing its resources tends to encourage local government to avoid waste. Therefore, having higher economic independence encourages the local government to be more efficient in its operations.

A higher level of economic independence is found to be associated with higher efficiency results of the local government (Loikkanen \& Susiluoto, 2005; BalaguerColl et al., 2007; Hauner 2008; Fogarty \& Mugera, 2013; Doumpos \& Cohen, 2014). Less dependence on grants or subsidies implies high financial independence. Local governments are also perceived as efficient when they can provide more goods and services within the limited amount of grants and subsidies (Lopez et al., 2009). Doumpos \& Cohen (2014) tested two different minimum adjustments on the resource allocation (grants amount) to analyse its impact on local government efficiency. The findings support their arguments that downsizing of the number of grants helps to reduce the burden as well as improving the efficiency of local government (Doumpos \& Cohen, 2014).

However, findings by Geys \& Moesen (2009) reveal a positive association between grants and efficiency, which also means a negative association between economic independence and local government efficiency. The possible reason for the favourable effect of having more grants (i.e. less economic independence) may have been due to the grant system which motivates the local government to increase its supervision of their expenditure (Geys \& Moesen, 2009). The new performance-based system indicates to Geys \& Moesen that grants would be better in promoting higher efficiency, thus suggesting that less economic independence is good for the local government.

Aligned with contingency theory, the present study predicts a positive association between economic independence and the local government's efficiency, where higher economic independence leads to higher efficiency, as indicated by the higher technical efficiency (TE) scores. Stricter utilisation of resources in producing services promotes higher pure technical efficiency (PTE). Likewise, the local government may choose the best scale of operation for higher efficiency, and this will be seen in the high scale efficiency (SE) scores. Therefore, for this study, three separate hypotheses are created to test the relationship. 
H3a: There is a positive relationship between the level of economic independence and technical efficiency.

H3b: There is a positive relationship between the level of economic independence and pure technical efficiency.

H3c: There is a positive relationship between the level of economic independence and scale efficiency.

\subsubsection{Dependence on Tax Revenue and Efficiency}

Tax revenue is a major component of local government revenue. This type of revenue relates directly to citizens. Studies have found a positive relationship between tax revenue and the efficiency of local government (De Borger \& Kerstens, 1996; Benito et al., 2010). De Borger \& Kerstens (1996) find a positive relationship between the two, where high taxes may increase public awareness in monitoring public expenditure. The more dependent the local government on tax revenue; the more intense the public scrutiny. This scrutiny may influence the efficiency of local government positively.

However, Balaguer-Coll et al. (2007) have found otherwise. They argue that tax revenues tend to decrease the efficiency of local government because when the revenue may be easily obtained through collecting taxes, the local government is less motivated to manage their revenue properly, and this negatively affects their efficiency. The lack of proper controls and monitoring of the tax revenue may also worsen the local government's efficiency level.

For this study, the researcher predicts a positive association between the dependence on tax revenues and local government efficiency. The PTE scores would be high because the local government would carefully organise their inputs (resources) to ensure that no resources are wasted. High SE scores may also be recorded where careful judgement on the scale of operation may be made on choosing the optimal scale. These high PTE and SE scores lead to high TE scores. Therefore, for this study, three separate hypotheses are created to test the relationship.

H4a: There is a positive relationship between the dependence on tax revenue and technical efficiency.

$H 4 b$ : There is a positive relationship between the dependence on tax revenue and pure technical efficiency.

H4c: There is a positive relationship between the dependence on tax revenue and scale efficiency.

\subsubsection{Value of Assets and Efficiency}

Apart from the labour, assets are an important item used by the local government in providing public services. Quality and functioning assets are necessary to help local governments to be more efficient in their job function. However, after a long period of usage, the assets may deteriorate in quality. When this happens, the local government may need to spend more time and money to refurbish the old assets, causing less focus on service provision.

Any decisions regarding capital spending by the local governments are closely related to their efficiency level. Capital spending can be related to the value of 
assets owned by the local government (Doumpos \& Cohen, 2014). A local government owning more new assets and infrastructure is perceived to be more efficient than other local governments that own assets that have been in use for years. A statistically significant positive association has been found between assets or infrastructure value and the efficiency of local government (Doumpos \& Cohen, 2014).

In this study, the researcher predicts a positive association between the value of assets owned by the local government and its efficiency. Having more new assets allows the local government to manage its resources better, and thus the PTE scores will be high. The SE scores would also be recorded high as using newer assets helps the local government to optimise their scale of operation. These high PTE and SE scores lead to high TE scores. Therefore, for this study, three separate hypotheses are created to test the relationship.

H5a: There is a positive relationship between the value of assets and technical efficiency.

H5b: There is a positive relationship between the value of assets and pure technical efficiency.

H5c: There is a positive relationship between the value of assets and scale efficiency.

\section{Research Methodology}

The current study uses secondary data. In particular, financial statements are used as the source of secondary data. The relevant financial information in the financial statement of local government is related to revenues and expenses extracted as the input and output variables used in measuring the efficiency (Fogarty \& Mugera, 2013; Da Cruz \& Marques, 2014; Doumpos \& Cohen, 2014). There are 149 local governments in Malaysia, of which 99 are located in Peninsular of Malaysia and the remaining 50 in Sabah and Sarawak (Local Government Department, 2016). For the current study, only the local governments in Peninsular Malaysia are covered. The main reason for excluding the local government in Sabah and Sarawak is because of the differences in the acts and regulations of the local government between Peninsular of Malaysia and Sabah and Sarawak. All the local governments in the Peninsular were established under the Local Government Act 1976 (Act 171), while the local governments in Sabah and Sarawak were established under the Local Government Ordinance 1961 and the Local Authorities Ordinance 1996, respectively (Khalid, 2010; Local Government Department, 2016). The differences in the regulations may affect the administration and the management of the local government. Therefore, the total sample of the present study is 99 local governments.

This study investigated factors influencing the efficiency of local government in Malaysia. In achieving this objective, multiple regression analysis was used. By conducting the Stata version 10, the regression analysis is performed using the ordinary least square (OLS) regression method. Dependent variables were regressed against independent variables that are most probably influencing the efficiency of the local government (Ibrahim \& Karim, 2004). The dependent variables are the efficiency scores derived from the Data Envelopment Analysis 
(DEA) method. DEA is a non-parametric programming method performed to establish the production frontier and to calculate efficiency of decision-making units (DMU) such as organisations or countries using the inputs the units consume and the outputs that they produce (Doumpos \& Cohen, 2014). The present study performs the standard DEA models (CRS and VRS) in analysing the efficiency level of local government in Malaysia. The efficiency measure uses in this model is technical efficiency (TE), which can be split into two components, namely pure technical efficiency (PTE) and scale efficiency (SE). The analyses are performed on individual local governments. The TE is represented by the CRS efficiency scores that measure efficiencies due to the combination of inputs and outputs as well as the size of operations (Avkiran, 1999), while the PTE is represented by the VRS efficiency scores that measure efficiencies without any consideration of the scale efficiency (Avkiran, 1999). As for the SE, it is a component of TE that relates to the size of the operation (Avkiran, 1999). The scale efficiency can be computed by dividing TE and PTE. The summary of the dependent variables is provided in Table 1.

Table 1. Dependent Variables

\begin{tabular}{ll}
\hline Dependent variables & Definitions \\
\hline TE & Technical efficiency $=$ PTE $\times$ SE \\
PTE & Pure technical efficiency $=$ TE / SE \\
SE & Scale efficiency $=$ TE / PTE \\
\hline
\end{tabular}

The inputs and outputs for the present study are the relevant financial information obtained from the audited financial statements of the local government. The summary of inputs and outputs are as tabulated in Table 2.

Table 2. Input and output variables

\begin{tabular}{ll}
\hline Inputs & Outputs \\
\hline 1. Tax revenues & 1. Land and buildings \\
2. Fees and charges & 2. Motor vehicles \\
3. Subsidies from central government & 3. Equipment and fittings \\
& 4. Cost of goods and services \\
\hline
\end{tabular}

For this study, tax revenues, fees and charges, and subsidies are used as inputs. The local government uses the revenues to provide the various services and facilities to the public. Similar information about local governments' total revenues has been used in prior studies, including Doumpos \& Cohen (2014) and El Mehdi \& Hafner (2014). This study adopted the value-based approach introduced by Doumpos \& Cohen (2014) to represent the outputs. The value-based approach uses the net book values of the assets as a proxy for the magnitude of the services provided and the cost of goods and services as a proxy of the value of resources used in the activity of providing these services. Assumptions are made where the higher net book value of the assets and the higher costs of goods and services indicate the magnitude and quality of services provided to the public. The four outputs for this study are the net book value of land and buildings, the net book value of motor vehicles, the net book value of equipment and fittings and the total cost of goods and services. 
The five independent variables for this study: are population size, population density, economic independence, dependence on tax revenues and the value of assets. The first and second independent variables are related to population characteristics. These population characteristics of size and density are expected to influence the performance of the local government because it is the local governments' responsibility to provide public services to the population in their respective areas. The other three independent variables are selected because they indicate the manner of the local government in managing their resources. Economic independence and dependence on tax revenues indicate the level of local governments' dependence on their source of income. The fifth independent variable - value of assets - represents the magnitude and the quality of services provided to citizens.

In terms of the population size, guided by the category of local government designated by the Local Government Department of Malaysia, the local governments in the sample are classified as large (population above 500,000 inhabitants) and small (population below 500,000 inhabitants). The population density is commonly related to the population size. For population density in local government areas, this study drew on the Population and Housing Census (2010) information issued by the Department of Statistics Malaysia. According to the information on states' population density, the samples in the present study are classified in terms of high-density population (more than 501 inhabitants per $\mathrm{km}^{2}$ ) and low-density population (less than 500 inhabitants per $\mathrm{km}^{2}$ ). Each of the classifications for population size and population density is associated with a dummy variable, thus enabling the consideration of a possible non-linear relationship between efficiency and population size. Dummy variable 1 is used to represent local government with high population size or high-density population, and dummy variable 0 is used to represent local government with low population size or low-density population.

The third independent variable is economic independence, which addresses the local governments' ability to financially support themselves with less dependence on subsidies (grants) from the central government. High economic independence is associated with the low number of subsidies received. Some prior studies found that the number of subsidies received by the local government closely related to their level of efficiency (De Borger \& Kerstens, 1996; BalaguerColl et al., 2007; Geys \& Moesen, 2009; Doumpos \& Cohen, 2014). In order to compute economic independence, this variable employs the ratio of own revenues (including fees, charges and taxes) to subsidies, as an indicator of economic independence from central government subsidies (Doumpos \& Cohen, 2014).

The fourth independent variable is dependence on tax revenue. As taxes do not correspond to a specific array of services, local government normally relies on the tax revenues when they are less successful in providing chargeable services to citizens. Higher dependence on tax revenues is related to an increase in public awareness of controlling a local government's expenditures, and this may affect local government efficiency. To compute the local government's dependence on tax revenues, this variable employs the tax revenues amount to take into account the level of the local government's dependence on tax collection (De Borger \& Kerstens, 1996). 
The fifth independent variable selected is the value of assets. Local governments use their assets in their function to provide public services, and all these assets require maintenance. Old assets tend to cause high maintenance costs, thus affecting the local government's efficiency. Following Doumpos \& Cohen (2014), this study examines the effect of these assets' age on the local government's efficiency level. For this purpose, the study uses the annual depreciation as an indicator of local government's assets' age. A local government with many new assets would show a higher annual depreciation amount in their books as the older assets would have already been fully depreciated. The independent variables are summarised in Table 3.

Table 3. Independent Variables and its Definitions

\begin{tabular}{|c|c|c|}
\hline $\begin{array}{l}\text { Independent } \\
\text { variables }\end{array}$ & Abbreviation & Definitions \\
\hline Population size & DUMPOP & $\begin{array}{l}\text { Dummy variable represents the population based on } \\
\text { number of populations in the area. }\end{array}$ \\
\hline Population density & DUMDEN & $\begin{array}{l}\text { Dummy variable that represents the estimated } \\
\text { population density by states in Malaysia. }\end{array}$ \\
\hline $\begin{array}{l}\text { Economic } \\
\text { independence }\end{array}$ & OWREV & $\begin{array}{l}\text { Own revenues including fees, charges and taxes to } \\
\text { subsidies ratio. Indicates the extent of local } \\
\text { government's dependence on } \\
\text { grants/transfers/subsidies from the central } \\
\text { government. }\end{array}$ \\
\hline $\begin{array}{l}\text { Dependence on tax } \\
\text { revenues }\end{array}$ & TXREV & $\begin{array}{l}\text { Tax revenues amount. Indicates the extent of local } \\
\text { government's dependence on tax income. }\end{array}$ \\
\hline Value of assets & ASSETS & $\begin{array}{l}\text { Annual depreciation amount. Indicates the age of } \\
\text { assets used in providing quality services to the public } \\
\text { because only new assets still have depreciation value, } \\
\text { whereas old assets have already fully depreciated. }\end{array}$ \\
\hline
\end{tabular}

Three separate regression models are developed for the respective dependent variables:

$\begin{aligned} \text { Model } 1 T E_{i t}= & a_{t}+\beta_{1} \text { DUMPOP }_{i t}+\beta_{2} \text { DUMDEN }_{i t}+\beta_{3} \text { OWREV } \\ & \beta_{5} \text { ASSETS }_{i t}+\epsilon_{4} \epsilon_{\text {TXREV }}\end{aligned}$

Model $2 \quad P_{T E}=a_{t}+\beta_{1}$ DUMPOP $_{i t}+\beta_{2}$ DUMDEN $_{i t}+\beta_{3} \mathrm{OWREV}_{i t}+\beta_{4} T$ TXREV $V_{i t}+$ $\beta_{5}$ ASSETS $_{i t}+\epsilon_{\text {it }}$

Model $3 \quad S E_{i t}=a_{t}+\beta_{1}$ DUMPOP $_{i t}+\beta_{2}$ DUMDEN $_{i t}+\beta_{3} O W R E V_{i t}+\beta_{4} T$ TXREV $V_{i t}+$ $\beta_{5}$ ASSETS $_{i t}+\epsilon_{i t}$

$T E=$ Technical efficiency. $P T E=$ Pure technical efficiency. $S E=$ Scale efficiency. $D U M P O P=$ Population size. DUMDEN=Population density. OWREV=Economic independence. TXREV=Dependence on tax revenue. ASSETS=Value of assets. $i=$ Number of the local government. $t=$ The time period (year). $\alpha=$ Constant term. $\beta=$ Vector of coefficient. $\epsilon=$ Error term 


\section{Findings and Discussion}

\subsection{Descriptive Analysis}

Table 4 presents the descriptive statistics of the dependent and independent variables for the eight years' panel data used in this study. The dependent variables are technical efficiency (TE), pure technical efficiency $(P T E)$ and scale efficiency $(S E)$, while the independent variables are the population size (DUMPOP), population density (DUMDEN), economic independence (OWREV), dependence on tax revenue (TXREV) and value of assets (ASSETS).

Table 4. Descriptive Statistics of the Dependent and Independent Variables for Panel Data from 2008 to 2015

\begin{tabular}{lllll}
\hline & $\mathrm{N}$ & Minimum & Maximum & Mean \\
\hline TE & 236 & 0.576 & 1.000 & 0.951 \\
PTE & 236 & 0.633 & 1.000 & 0.979 \\
SE & 236 & 0.672 & 1.000 & 0.970 \\
DUMPOP & 236 & 0.000 & 1.000 & - \\
DUMDEN & 236 & 0.000 & 1.000 & - \\
OWREV & 236 & 0.300 & 108.580 & 8.155 \\
TXREV & 236 & 0.050 & $1,060.070$ & 56.578 \\
ASSETS & 236 & 0.070 & 102.010 & 5.600 \\
\hline
\end{tabular}

The maximum and minimum values of technical efficiency (TE) are 1.000 and 0.576 , respectively, while the mean is 0.951 . For pure technical efficiency, the maximum, minimum and mean values are recorded at 1.000, 0.633 and 0.979 respectively. The scale efficiency $(S E)$ maximum values are stated as 1.000 , while the minimum values are stated as 0.672 , and the mean value is stated as 0.970 . This study reveals high mean values for the TE, PTE and SE, indicating that most of the local governments achieved relatively high efficiency scores.

Two of the independent variables, namely the population size (DUMPOP) and population density (DUMDEN), are represented by dummy variables. The population size is represented by dummy variable 1 for local governments with high population size and dummy variable 0 for low population size. For population density, dummy variable 1 represents high dense population and dummy variable 0 represents a low dense population. Therefore, the minimum value for these two variables is recorded at zero and the maximum value at 1.000.

For the economic independence (OWREV) variables, the maximum and minimum value recorded is 108.580 and 0.300 , respectively, with the mean value stated at 8.155 . This indicates that on average, a local government's revenue, i.e. fees, charges and taxes, is eight times the number of subsidies received from the central government. For dependence on tax revenue (TXREV), the maximum, minimum and mean values are stated at RM1,060.070 million, RM0.050 million and RM56.578 million, respectively, and the value of assets' (ASSETS) variable maximum, minimum and mean value is RM102.010 million, RM0.070 million and RM5.600 million respectively. Both mean values, i.e. dependence on tax revenue, and the value of assets reveal the average of the 8-year panel data, where the average tax revenue amount is RM56.578 million, and the average annual depreciation is RM5.6 million. 


\subsection{Factors Affecting Efficiency Level}

To investigate the factors, the study performs an ordinary least square (OLS) multiple regression analysis. Three multiple regression models were developed, where the efficiency measures of technical efficiency $(T E)$, pure technical efficiency $(P T E)$ and scale efficiency $(S E)$ are the dependent variables for each of the models. There are five independent variables for each model: population size (DUMPOP), population density (DUMDEN), economic independence (OWREV), dependence on tax revenues (TXREV) and value of assets (ASSETS). Before the results of the multiple regressions are presented, the preliminary statistical tests of normality test and multicollinearity test were performed. The results of OLS regression for three different models are presented in Table 5. As shown in Table 5, all the three models are significant at 0.01 level with adjusted $\mathrm{R}^{2}$ ranging from $5.7 \%$ to $12.8 \%$.

Table 5. OLS Regression Results of Efficiency Scores

\begin{tabular}{|c|c|c|c|}
\hline \multirow{3}{*}{ Independent variables } & \multicolumn{3}{|c|}{ Dependent variables } \\
\hline & Model 1 & Model 2 & Model 3 \\
\hline & $T E$ & PTE & $S E$ \\
\hline \multirow[t]{2}{*}{ Constant } & 0.965 & 0.998 & 0.967 \\
\hline & $(0.000)$ & $(0.000)$ & $(0.000)$ \\
\hline \multirow[t]{2}{*}{ DUMPOP } & 0.008 & 0.029 & -0.020 \\
\hline & $(0.673)$ & $(0.028)^{* *}$ & $(0.120)$ \\
\hline \multirow[t]{2}{*}{ DUMDEN } & -0.001 & 0.002 & -0.003 \\
\hline & $(0.936)$ & $(0.845)$ & $(0.807)$ \\
\hline \multirow[t]{2}{*}{ OWREV } & 0.064 & -0.000 & 0.065 \\
\hline & $(0.000)^{*}$ & $(0.987)$ & $(0.000)^{*}$ \\
\hline \multirow[t]{2}{*}{ TXREV } & -0.062 & -0.036 & -0.028 \\
\hline & $(0.000)^{*}$ & $(0.001)^{*}$ & $(0.007)^{*}$ \\
\hline \multirow[t]{2}{*}{ ASSETS } & 0.033 & 0.043 & -0.008 \\
\hline & $(0.129)$ & $(0.005)^{*}$ & $(0.593)$ \\
\hline No. of observation & 236 & 236 & 236 \\
\hline R-squared & 0.077 & 0.087 & 0.147 \\
\hline Adj. R-squared & 0.057 & 0.067 & 0.128 \\
\hline \multirow{2}{*}{ F-statistics } & 3.83 & 4.39 & 7.92 \\
\hline & $(0.002)^{*}$ & $(0.001)^{*}$ & $(0.000)^{*}$ \\
\hline
\end{tabular}

Values in parentheses are $p$ values. ${ }^{*},{ }^{* *}$ indicates significance at 0.01 and 0.05 level respectively.

As shown in Table 5, population size (DUMPOP) is found to have a significant and positive relationship with the PTE. Therefore, $H 1 b$ is supported while $H 1 a$ and $H 1 c$ are not supported. This finding aligns with some of the prior literature, which found that larger population size helps local governments to be efficient (Benito et al., 2010; Doumpos \& Cohen, 2014; Wibowo \& Alfen, 2015). Local governments with larger population size receive a higher amount of revenues, which allows them to operate better than local governments with smaller population size. The high revenues permit local governments to invest in more advanced facilities and skilled employees. Better allocation of resources leads to an increase in the local government's efficiency, which reflects its higher PTE scores.

Despite the argument by Wibowo \& Alfen (2015) that larger population size encourages economy of scale and thus savings to a local government's resources, the findings of this study suggested otherwise. Local governments with a high population size are found not to be operating at their optimal scale, and this leads 
to lower scale efficiency. Large population size indicates a positive relationship with the overall efficiency, i.e. technical efficiency (TE) scores; however, the relationship is not significant. The unfavourable effect of a wrong scale of operation may have weakened the benefits of having developed technologies and talented staff.

The findings reveal that there is no statistically significant relationship between population density (DUMDEN) and efficiency (TE, PTE and SE) scores. Thus, H2a, $\mathrm{H} 2 \mathrm{~b}$ and $\mathrm{H} 2 \mathrm{c}$ are not supported. Some prior studies reveal that higher density of population generates a higher volume of waste, and this causes difficulty for the local government in handling refuse collection (Geys \& Moesen, 2009; BenitoLópez et al., 2011; Da Cruz \& Marques, 2014; Doumpos \& Cohen, 2014). The cost of operations would increase and lead to improper allocation of resources. Although the population density increases the local government service costs, the income generated by the highly-dense population may also increase. High population density would create higher demand for property. A limited number of properties may lead to an increase in property prices. As a result, local government revenue may also increase. This may be the reason why this study has not found any significant result for the relationship between this variable and the efficiency measures.

The findings on the relationship between efficiency and both independent variables related to population may also provide some indication that initiative on transferring some of the local governments' services to the state government or the federal government has succeeded in securing the local government's performance. The population size or density may no longer have a substantial impact on local governments' efficiency as the leading public service, i.e. solid waste and public cleansing management, is being managed by the state or federal government.

Economic independence (OWREV) is found to have a significant and positive relationship with the TE and SE. Therefore, $H 3 a$ and $H 3 c$ are supported. Higher economic independence means less dependence on grants and subsidies from the central government. In other words, lower grants encourage higher and better efficiency in local government. The result of this study supports the earlier findings by De Borger \& Kerstens (1996), Loikkanen \& Susiluoto (2005), BalaguerColl et al. (2007), Doumpos \& Cohen (2014) and Da Cruz \& Marques (2014), who found that dependence on grants and subsidies demotivates local government in monitoring its spending, and this eventually leads to a local government's inefficiency. The findings indicate that only the TE and SE have a significant and positive association with OWREV. This suggests that local governments will be more cautious in spending their income if they have put their effort into obtaining it. Moreover, the local government may emphasise the optimum size of operation to ensure that the resources are utilised at the correct scale, and this may lead to high SE, which in turn, maximises the output using the limited resources available, i.e. high TE. However, there is no significant association found between economic independence and PTE scores. Thus, H3b is not supported. This indicates that having economic independence does not ensure the proper allocation of resources.

The dependence on tax revenue (TXREV), is found to be negatively and significantly associated with all the efficiency measures. This indicates that the 
increase in tax revenues reduces local government's motivation in improving their efficiency (Balaguer-Coll et al., 2007). The easily generated income makes the local government feel at ease and put less effort to manage the revenue income well. From the findings, TXREV is significantly and negatively associated with the TE, PTE and SE. It can be implied that dependence on tax revenue would negatively affect a local government's way of managing their inputs or resources as well as their choice on the scale of operations. Thus, $H 4 a, H 4 b$ and $H 4 c$ are not supported.

The results show a positive and statistically significant association between the value of assets (ASSETS) and the pure technical efficiency only. However, there is no significant association found between the ASSETS and TE and SE. Therefore, $\mathrm{H} 5 \mathrm{~b}$ is supported while $\mathrm{H} 5 \mathrm{a}$ and $\mathrm{H} 5 \mathrm{c}$ are not supported. This indicates that having new assets may not help a local government in improving its overall efficiency. Although new assets allow quality services, the assets would lead to a change in the scale of operation, which may indirectly affect the local government scale efficiency. The positive and significant relationship between a local government's value of assets and pure technical efficiency (PTE) may indicate an increase in the local government's effort to ensure appropriate allocation of resources in producing quality public services in line with the requirement of the MS ISO 9000 quality system. This proves that the introduction of the quality system has made some contribution to growing motivation in local government for better efficiency. This finding aligns with the earlier prediction that newer assets require lower maintenance and operating expenses, allowing a local government to focus more on advanced technology that could lead to higher efficiency (Doumpos \& Cohen, 2014).

\subsection{Implications, Limitations, Suggestions for Future Study and Conclusions}

The regression results reveal that among the five independent variables, only four of the variables - population size (DUMPOP), economic independence (OWREV), dependence on tax revenue (TXREV) and value of assets (ASSETS) - are found to have a significant relationship with some or all the efficiency measures. Population size is positively associated with the PTE, while economic independence is positively related to the TE and $S E$. Dependence on tax revenue has a negative relationship with all the efficiency measures of TE, PTE, SE and value of assets is positively associated with the PTE. No significant relationship is found in population density (DUMDEN).

Identifying the factors influencing the efficiency of the respective local governments is useful in assisting them to understand the reason for their efficiency scores. The positive relation between the efficiency (TE and SE) scores and economic independence would suggest that efficiency may be improved if the local governments put more effort into obtaining their revenue instead of depending on grants. A higher level of economic independence motivates a local government to choose the best size of operation in providing services. In terms of the population size and value of assets are positively and significantly associated with the PTE scores only. Therefore, a local government with a larger population or many newly invested assets should regularly review its way of managing the resources to ensure proper allocation is made. 
The negative relationship between the efficiency scores (TE, PTE, SE) and the dependence of tax revenue suggests that proper tax revenue spending may help in maintaining a satisfactory level of efficiency. Aside from establishing a strict guideline of tax revenue spending, local government should also put more effort into creating other sources of income in order to lessen the dependency on the tax revenue.

The current study suffers from several limitations. One limitation is on the selection of the factors influencing efficiency. Selections of the factors are not exhaustive, and some other related and important factors may not have been selected. The study selected only the factors which were available from the local governments' annual financial statements. The qualitative data on the magnitude of services which are not available in the financial statements are excluded. Further research may also be performed to examine the possible reasons for differences in the efficiency scores between the local government in Peninsular Malaysia, Sabah and Sarawak. The present study has focused only on examining the efficiency of local government and has not been able to assess the effectiveness of these services - lack of effectiveness and not just lack of efficiency may well be a factor in public complaints. Future research may also be extended to evaluate the effectiveness of public services, including public satisfaction in order to better justify the various public complaints.

Despite the limitations, the present study provides some useful indications of the factors influencing the different efficiency levels, which may help enhance the understanding of the performance of the local government in Malaysia.

\section{References}

Abdullah, S., Razak, A.A., Hanafi, M.H., \& Jaafar, M. (2013). Implementation barriers of ISO 9000 within the Malaysian local government. International Journal of Quality and Reliability Management, 30(8), 853-876. https:// doi.org/10.1108/IJQRM-Dec-2011-0160.

Avkiran, N.K. (1999). An application reference for data envelopment analysis in branch banking: helping the novice researcher. International Journal of Bank Marketing, 17(5), 206-220. https:// doi.org/10.1108/02652329910292675

Balaguer-Coll, M.T., Prior, D., \& Tortosa-Ausina, E. (2007). On the determinants of local government performance: A two-stage non-parametric approach. European Economic Review, 51(2), 425-451. https:/ / doi.org/10.1016/j.euroecorev.2006.01.007

Benito, B., Bastida, F., \& García, J.A. (2010). Explaining differences in efficiency: an application to Spanish municipalities. Applied Economics, 42(4), 515-528. https://doi.org/10.1080/00036840701675560

Benito-López, B., Moreno-Enguix, M.D.R., \& Solana-Ibañez, J. (2011). Determinants of efficiency in the provision of municipal street-cleaning and refuse collection services. Waste Management, 31(6), 1099-1108. https://doi.org/10.1016/j.wasman.2011.01.019

Borger, B.D., \& Kerstens, K. (1996). Cost efficiency of Belgian local governments: A comparative analysis of FDH, DEA, and econometric approaches. Regional Science and Urban Economics, 26(2), 145-170. https://doi.org/10.1016/0166-0462(95)02127-2

Cruz, N.F.D., \& Marques, R.C. (2014). Revisiting the determinants of local government performance. Omega, 44, 91-103. https:// doi.org/10.1016/j.omega.2013.09.002

Department of Statistics Malaysia (2016). Population Distribution and Basic Demographic Characteristic Report 2010. Retrieved from https:/ /www.dosm.gov.my/

Donaldson, L. (2001). The contingency theory of organisations. Thousand Oaks, CA: Sage Publications. 
Doumpos, M., \& Cohen, S. (2014). Applying data envelopment analysis on accounting data to assess and optimise the efficiency of Greek local governments. Omega, 46, 74-85. https:// doi.org/10.1016/j.omega.2014.02.004

Fogarty, J., \& Mugera, A. (2013). Local Government Efficiency: Evidence from Western Australia. Australian Economic Review, 46(3), 300-311. https:/ / doi.org/10.1111/j.1467-8462.2013.12015

Geys, B., \& Moesen, W. (2009). Exploring sources of local government technical inefficiency: Evidence from Flemish municipalities. Public Finance and Management, 9(1), 1-29.

Ghobadian, A., \& Ashworth, J. (1994). Performance Measurement in Local Government - Concept and Practice. International Journal of Operations and Production Management, 14(5), 35-51. https://doi.org/10.1108/01443579410056786.

Grötsch, V.M., Blome, C., \& Schleper, M.C. (2013). Antecedents of proactive supply chain risk management - a contingency theory perspective. International Journal of Production Research, 51(10), 2842-2867. https:/ / doi.org/10.1080/00207543.2012.746796

Hauner, D. (2008). Explaining Differences in Public Sector Efficiency: Evidence from Russia's Regions. World Development, $36(10), \quad 1745-1765$. https://doi.org/10.1016/j.worlddev.2007.09.011

Ibrahim, F., \& Karim, M.Z. (2004). Efficiency of local government in Malaysia and its correlates. International Journal of Management Studies, 11(1), 57-70.

Kalb, A., Geys, B., \& Heinemann, F. (2011). Value for money? German local government efficiency in a comparative perspective. Applied Economics, 44(2), 201-218. https:// doi.org/10.1080/00036846.2010.502110

Mehdi, R.E., \& Hafner, C.M. (2014). Local Government Efficiency: The Case of Moroccan Municipalities. African Development Review, 26(1), 88-101. https://doi.org/10.1111/14678268.12066

Local Government Department. (2015). Local Authority Statistics. Retrieved from http://jkt.kpkt.gov.my/

Loikkanen, H.A., \& Susiluoto, I. (2005). Cost efficiency of Finnish municipalities in basic service provision 1994-2002.

Ngah, K. (2011). The future challenges of local authorities in Malaysia: A case study in Seberang Perai, Penang. African Journal of Business Management, 5(26). https://doi.org/10.5897/AJBM11.1445

Osman, M.M., Bachok, S., Bakri, N.I.M., \& Harun, N.Z. (2014). Government Delivery System: Effectiveness of Local Authorities in Perak, Malaysia. Procedia Social and Behavioral Sciences, 153, 452-462. https:// doi.org/10.1016/j.sbspro.2014.10.079

Phang, S.N. (2008). Decentralisation or Recentralisation? Trends in local government in Malaysia. Commonwealth Journal of Local Governance, 1, 126-132. https:/ / doi.org/10.5130/cjlg.v1i0.759

Public Complaints Bureau. (2016). Statistics by year. Retrieved from http://www.pcb.gov.my/

Revelli, F., \& Tovmo, P. (2007). Revealed yardstick competition: Local government efficiency patterns in Norway. Journal of Urban Economics, 62(1), 121-134. https://doi.org/10.1016/j.jue.2006.11.004

Storto, C.L. (2013). Evaluating Technical Efficiency of Italian Major Municipalities: A Data Envelopment Analysis model. Procedia Social and Behavioral Sciences, 81, 346-350. https:// doi.org/10.1016/j.sbspro.2013.06.

Wadongo, B., \& Abdel-Kader, M. (2014). Contingency theory, performance management and organisational effectiveness in the third sector. International Journal of Productivity and Performance Management, 63(6), 680-703. https:/ / doi.org/10.1108/IJPPM-09-2013-0161

Wibowo, A., \& Alfen, H.W. (2015). Benchmarking the efficiencies of Indonesia's municipal water utilities using Stackelberg data envelopment analysis. Benchmarking: An International Journal, 22(4), 588-609. https:/ / doi.org/10.1108/BIJ-01-2014-0009

Yahaya, N., \& Larsen, I. B. (2008). Federalising solid waste management in peninsular Malaysia. In Proceeding of International Solid Waste Association (ISWA) World Congress, Singapore. 